\title{
УАK 336.7
}

Ю. В. Великий, А. е. н., професор, професор кафеАри обліку і аудиту, Чорноморський національний університет імені Петра Могили ORCID ID: 0000-0002-7714-0840

K. $\Lambda$. Нетудихата, к. е. н., Аоцент, доцент кафеАри менеАжменту, Чорноморський національний університет імені Петра Могили, м. Миколаїв ORCID ID: 0000-0002-5322-4986

T. Ю. Пігар, магістр факультету економічних наук, Чорноморський національний університет імені Петра Могили, м. Миколаїв ORCID ID: 0000-0002-9949-9432

\section{ЕКСПРЕС-АІАГНОСТИКА ЯКОСТІ КРЕАИТНОГО ПОРТФЕАЯ БАНКІВ}

\author{
Yu. Velikiy, \\ Doctor of Economic Science, Professor, Professor of Accounting \\ and Audit Cathedra, Petro Mohyla Black Sea National University, Mykolaiv \\ K. Netudyhata, \\ Candidate of Economic Science, Associate Professor \\ of Management Cathedra, Petro Mohyla Black Sea National University, Mykolaiv \\ T. Pigar, \\ Magister of Economic Sciences Faculty, Petro Mohyla Black Sea National University, Mykolaiv
}

\section{EXPRESS DIAGNOSTICS OF BANK LOAN PORTFOLIO QUALITY}

У статті розкрито питання властивостей та критеріїв якості кредитного портфеля банків. Запропоновано метоАику експрес-діагностики якості кредитного портфеля банків, що будується на інтеградьній оцінці. Остання враховує сукупність чинників із застосуванням прийнятих сьогодні критеріїв якості креАитного портфеля (ризик, прибутковість, ліквідність).

Проведено експрес-діагностику якості кредитного портфеля п'яти великих банків. Встановлено, що після останньої фінансової кризи стан їхніх портфелів став поліпшуватися. Аля деяких банків якість кредитного портфеля залишається низькою переважно через проблеми з ліквідністю портфеля. Побудовано економетричні моделі, які відображають вплив екзогенних факторів на якість кредитного портфеля. Виявлено вплив таких факторів, як структура портфелів за видами валют та рентабельність кредитних операцій.

Запропоновано банківським установам проводити комплексну політику забезпечення якості кредитного портфеля, щоб підвищити конкурентоспроможність та гарантувати безпеку свого функціонування.

The article deals with the properties and quality criteria of banks' credit portfolio. The quality of a bank's loan portfolio is determined by its ability to provide the maximum possible percentage return on credit operations at acceptable levels of liquidity and credit risk. Properties regarding the quality of the loan portfolio should be identified and presented in the form of quantitative and qualitative indicators. The indicators found are compared with the criteria.

The method of express diagnostics of the quality of banks' credit portfolio, which is based on the integral evaluation, is proposed. The latter takes into account a set of factors using the credit portfolio quality criteria adopted today (risk, profitability, liquidity). An algorithm for calculating an integral portfolio quality index based on weighted average estimates of the level of individual criteria is proposed. The use of an integral indicator will allow to evaluate the state of the bank in the country's banking market or the dynamics of the qualitative characteristics of its credit portfolio.

Express diagnostics of the quality of the loan portfolio of five large banks (with loan portfolios exceeding UAH 10 billion) was carried out. It was found that after the last financial crisis, their portfolios began to improve. For some banks, the quality of the loan portfolio remains low mainly due to portfolio liquidity problems. There are banks that are unable to meet the $\mathrm{N} 9$ standard. It is suggested that banking institutions implement a comprehensive quality policy for the loan portfolio to enhance competitiveness and ensure the safety of their operations. 
Econometric models have been constructed that reflect the impact of exogenous factors on the quality of the loan portfolio. The influence of such factors as the structure of portfolios by types of currencies and the profitability of credit operations are established. Therefore, due to the increase in the share of national currency loans and the correlation of interest income and expenses, banking institutions can improve the quality of their portfolios.

Ключові слова: експрес-діагностика, кредитний порторель, інтегральна очінка, ризик, прибутковість, ліквідність.

Key words: express diagnostics, credit portfolio, integral valuation, risk, profitability, liquidity.

\section{ПОСТАНОВКА ПРОБЛЕМИ}

Остання фінансова криза загострила проблеми розвитку вітчизняної системи банківського кредитування, серед яких істотне значення мало зростання непрацюючих кредитів, що призвело до зниження якості кредитного портфеля банків. У той же час аналіз тенденцій банківського кредитування показав, що більшість банків в умовах посткризового розвитку економіки для підтримки своєї конкурентоспроможності продовжують збільшувати обсяги виданих кредитів, зберігається ризик їх неповернення. Управління якістю кредитного портфеля забезпечує компроміс прибутковості, ліквідності та прийнятного для банку кредитного ризику. Внаслідок цього високі темпи банківських запозичень нині посилюють потребу в розробці методики експрес-діагностики якості кредитного портфеля банків та її застосування під час обгрунтуванні управлінських рішень, що дозволить підвищити конкурентоспроможність та безпеку функціонування сучасних банків.

\section{АНАЛІЗ ОСТАННІХ ДОСЛІДЖЕНЬ І ПУБЛІКАЦІЙ}

Загальнотеоретичні основи якості кредитного портфеля комерційного банку знайшли своє відображення в наукових працях: М.М. Авсєйко, А.Б. Басс, Н.І. Волкової, А.О. Кункель, О.І. Ааврушина, І.В. Ааріонової, П.С. Роуз, А.М. Тавасієва. В ході аналізу ступеня розробленості досліджуваної проблеми виявлено, що до теперішнього часу практично відсутні публікації, що присвячені експрес-діагностиці якості кредитного портфеля банків. Слід вказати, що більшість робіт засновано на аналізі окремих критеріїв якості, до їх числа відносяться праці: Т.В. Гребенник, Н.І. Валенцової, O.I. Ааврушина, I.А. Мамонтової, О.П. Тернівської.

Високо оцінюючи результати, що отримані в зазначених роботах, вважаємо за необхідне зазначити, що залишається ще чимало аспектів, які вимагають більш поглибленого аналізу, внесення уточнень та доопрацювання. Вивчення наукових здобутків названих авторів показало, що є розбіжності при трактуванні поняття кре- дитного портфеля банківської установи, визначенні критеріїв його якості та виборі системи фінансових коефіцієнтів, які доцільно використовувати для діагностики. Крім того, відсутні комплексні доробки щодо методичного інструментарію експрес-діагностики якості кредитного портфеля банків.

\section{META CTATT}

Метою статті $€$ теоретичне обгрунтування та розробка методичного інструментарію експрес-діагностики якості кредитного портфеля банків та його застосування під час обгрунтування управлінських рішень.

\section{ВИКЛАД ОСНОВНОГО МАТЕРІАЛУ}

Основним вИдом діяльності бУдь-якої банківської установи $є$ кредитування, яке дає можливість отримувати банкам доходи за умови правильної та раціональної кредитної політики. Ефективність проведених кредитних операцій залежить від якості сформованого кредитного портфеля. У поточних умовах діяльності банківських установ якість кредитного портфеля стає провідним фактором для успішного банку як комерційної організації.

У наукових роботах зустрічаються різні трактування кредитного портфеля, безліч наукових підходів до його структури та місця в портфелі банків. Так, А.М. Тавасієв трактує портфель як сукупність кредитів, що видані банком на кожен момент часу [8, с. 514]. Водночас сукупність структурована за певним критерієм, який є істотним для кредитів. А.Б. Басс зазначає, що кредитний портфель - це сукупність залишків заборгованості по активних кредитних операціях на певну дату [2, с. 43]. I.В. Ааріонова вказує, що кредитний портфель є сукупністю однорідних груп кредитних вкладень [5, с. 47]. Н.І. Волкова та А.О. Кункель розкривають сутність кредитного портфеля як сукупність усіх банківських позик, що структуровані за певними параметрами відповідно до завдань визначеної банком кредитної політики [3, с. 55]. O.I. Ааврушин трактує його так: сукупність виданих позик, які класифікуються на основі критеріїв, що пов'язані з різними факторами кредитного ризику або способами за- 
Таблиця 1. Критеріальні рівні показників якості кредитного портфеля

\begin{tabular}{|c|c|c|c|c|c|}
\hline Напрям оцінки & Показник & Контрольний рівень & $\begin{array}{c}\text { Вище контрольного } \\
\text { рівня }\end{array}$ & $\begin{array}{c}\text { Нижче контрольного } \\
\text { рівня }\end{array}$ & $\begin{array}{c}\text { Частка } \\
\text { показника, \% }\end{array}$ \\
\hline \multirow[t]{2}{*}{$\begin{array}{l}\text { 1. Дохідність } \\
\text { портфеля }\end{array}$} & 1.1. Коефіцієнт дохідності & \multirow[t]{2}{*}{$\begin{array}{l}\text { На рівні банківської } \\
\text { системи. } \\
10 \text { балів }\end{array}$} & \multirow[t]{2}{*}{$\begin{array}{l}\text { 11-20 балів (1 бал за } \\
\text { кожен розрахунковий } \\
\text { процентний пункт } \\
\text { перевищення) }\end{array}$} & \multirow{2}{*}{$\begin{array}{l}0-9 \text { балів (1 бал за } \\
\text { кожен розрахунковий } \\
\text { відсотковий пункт } \\
\text { нижче контрольного } \\
\text { рівня) }\end{array}$} & 15 \\
\hline & 1.2. Рентабельність портфелю & & & & 20 \\
\hline $\begin{array}{l}\text { 2. Рівень кредитного } \\
\text { ризику }\end{array}$ & $\begin{array}{l}\text { 2. Співвідношення резервів } \\
\text { до кредитного портфелю }\end{array}$ & $\begin{array}{l}\text { На рівні банківської } \\
\text { системи. } \\
10 \text { балів. }\end{array}$ & $\begin{array}{l}0-9 \text { балів (1 бал за } \\
\text { кожен розрахунковий } \\
\text { процентний пункт } \\
\text { перевищення) }\end{array}$ & $\begin{array}{l}\text { 11-20 балів (1 бал за } \\
\text { кожен розрахунковий } \\
\text { процентний пункт } \\
\text { нижче контрольного } \\
\text { рівня) }\end{array}$ & 30 \\
\hline \multirow[t]{2}{*}{$\begin{array}{l}\text { 3. Рівень ліквідності } \\
\text { портфеля }\end{array}$} & 3.1. Норматив Н7 & $\begin{array}{l}\text { Норматив 25\% (не } \\
\text { більше). } \\
10 \text { балів }\end{array}$ & \multirow[t]{2}{*}{$\begin{array}{l}\text { 0-9 балів (1 бал за } \\
\text { кожен розрахунковий } \\
\text { процентний пункт } \\
\text { перевищення) }\end{array}$} & \multirow[t]{2}{*}{$\begin{array}{l}11-20 \text { балів (1 бал за } \\
\text { кожен розрахунковий } \\
\text { процентний пункт } \\
\text { нижче контрольного } \\
\text { рівня) }\end{array}$} & 15 \\
\hline & 3.2. Норматив Н9 & $\begin{array}{l}\text { Норматив 5\% (не } \\
\text { більше). } \\
10 \text { балів }\end{array}$ & & & 20 \\
\hline
\end{tabular}

хисту від нього [4, с. 78]. Проведене дослідження дозволяє авторам дати таке визначення: кредитний портфель - це структурована за певними критеріями якості сукупність кредитів, виданих банківською установою відповідно до ії кредитної політики.

Кредитний портфель як економічна категорія визначається в прояві трьох функцій. Розподільна функція полягає в розподілі та перерозподілі позичкового капіталу в розрізі суб'єктів, що отримують кредитні кошти. Функція заміщення дійсних грошей кредитними операціями, що стимулює зростання платоспроможного попиту населення за допомогою надання кредитів. Функція мінімізації кредитного ризику дозволяє на основі постійного моніторингу проводити кредитні операції та формувати об'єктивну інформацію щодо клієнтів банку [4, с. 82].

Поняття якості є складним та багатогранним. Аосить часто в економічній літературі властивості та якість ототожнюються. Водночас зустрічається думка, що властивість це атрибут предмета, прояв його якості. Властивості чогонебудь можуть проявлятися в процесі взаємодії об'єктів. Стосовно кредитного портфелю, узагальненою властивістю $є$ структурована сукупність позичок, ранжованих в залежності від різних критеріїв, як-от: прибутковість, ліквіАність, частка простроченої заборгованості, частка сформованих резервів на можливі втрати. Основними складовими якості предмета виступають його властивості. Властивості, щодо якості кредитного портфеля, потрібно виявляти і представляти у вигляді кількісних та якісних показників. Виявлені показники порівнюються 3 критеріями. Критерій - це база порівняння, виявлені властивості кредитного портфеля можуть знайти відображення в кількісних та якісних показниках.
Сьогодні існує безліч пропозицій з приводу критеріїв якості кредитного портфеля. A.M. Тавасієв якість кредитного портфеля банку розглядає з використанням таких критеріїв, як прибутковість, ступінь кредитного ризику і забезпеченість [8, с. 515]. А.Б. Басс під якістю кредитного портфеля розуміє таку властивість його структури, яка має здатність забезпечувати максимальний рівень прибутковості при допустимому рівні кредитного ризику та ліквідності балансу [2 с. 43]. П.С. Роуз досліджує якість кредитного портфеля банку, акцентуючи увагу на таких критеріях, як оцінка ризику і надійність банку [7, с. 176]. М.М. Авсєйко зазначає, що поряд 3 кредитним ризиком критеріями якості кредитного портфеля виступають також його ліквідність та прибутковість. $[1$, c. 36]. Отже, формування банками кредитних портфелів являє собою не випадкове об'єАнання кредитних активів, а цілеспрямовану діяльність зі структурування кредитних вимог 3 точки зору забезпечення оптимального рівня прибутковості, ліквідності, а також прийнятного рівня ризику по кредитах. Аоцільно виділити три основні критерії якості портфелів: ризик (кредитний ризик), прибутковість та ліквідність.

Слід зазначити, що якість кредитного портфеля суттєво впливає на рівень його кредитної активності. Сьогодні активізувалася діяльність кредитних організацій в напрямі кредитування своїх клієнтів, що змушує їх звертати увагу на якість та можливість диверсифікації кредитного портфеля. Очевидно, що експрес-діагностика якості кредитного портфеля банків дозволить запобігти можливим кредитним ризикам та втратам у зв'язку з непродуманою кредитною політикою. 
Як зазначають Ейхлер $\Lambda . В$. та Гавриленко Н.Г. експрес-діагностика передбачає невеликі витрати часу для отримання попередньої оцінки. Аля більш детального аналізу проводяться додаткові аналітичні дослідження по виділених напрямках. Мета ії проведення - знайти та виділити найбільш складні проблеми управління організацією [10, с. 13]. Загалом роль діагностики полягає в інформаційно-аналітичному забезпеченні процесу прийняття та реалізації управлінського рішення на рівні банківської установи. Від того наскільки достовірна та повна інформація формується в процесі діагностики, залежить якість прийнятого рішення.

На нашу думку, експрес-діагностика якості кредитного портфеля банків повинна будуватися на інтегральній оцінці, яка враховує сукупність чинників із застосуванням прийнятих сьогодні критеріїв якості кредитного портфеля [9, с. 6]. Аоцільно під час розрахунку інтегрального показника якості портфеля використати підхід середньозваженої оцінки рівня окремих критеріїв (табл. 1). Застосування інтегрального показника дозволить провести порівняльну експрес-діагностику якості кредитного портфеля банківських установ або оцінити динаміку якісних характеристик портфеля окремого банку.

Аохідність кредитного портфеля планується оцінити за коефіцієнтом дохідності та рентабельністю. Перший показник визначається як співвідношення процентних доходів до кредитного портфеля. Аругий - як співвідношенням чистих процентних доходів (різниця між процентними доходами та витратами) до кредитного портфеля. Рівень кредитного ризику визначається за співвідношенням резервів до кредитного портфелю. Рівень ліквідності портфеля відображає швидкість продажу кредитів. Нормативи Н7 та Н9 використовуються для оцінки ліквідності [6].

Формули розрахунку балів:

Випадок 1. Чим більше значення показника, тим вище якість кредитного портфеля (коефіцієнт дохідності, рентабельність портфеля):

$\Pi б=(3 \mathrm{H}-\mathrm{Kp}) /(\mathrm{Kp}: 10)+10$

Випадок 2. Чим менше значення показника, тим вище якість кредитного портфеля (співвідношення резервів до кредитного портфеля, нормативи $\mathrm{H} 7$ та $\mathrm{H} 9)$ :

Пб $=(\mathrm{Kp}-3 \mathrm{H}) /(\mathrm{Kp}: 10)+10$

де Пб - кількість балів відповідно до значення показника;

Кр - контрольний рівень;

3н - значення показника, що розраховано по даним банку.
Якщо розмір відхилення фактичного значення від граничного більше $100 \%$, то цьому показнику дається оцінка в 0 (або 20) балів.

Таким чином, інтегральний показник якості кредитного портфеля буде мати вид:

$\mathrm{I}=0,15 * \Pi \sigma_{1.1}+0,20 * \Pi \sigma_{1} 2+0,30 * \Pi \sigma_{2}+$ $+0,15 * \Pi \sigma_{3.1}+0,20 * \Pi \sigma_{3.2}$

де I - інтегральний показник якості кредитного портфеля;

Пб ${ }_{1.1}$ - бали по коефіцієнту дохідності кредитного портфеля;

Пб ${ }_{1.2}$ - бали по рентабельності кредитного портфеля;

Пб ${ }_{2}$ - бали по співвідношенню резервів до кредитного портфеля;

Пб ${ }_{3.1}$ - бали по нормативу H7;

Пб ${ }_{3.2}^{3.2}$ - бали по нормативу Н9.

Водночас за допомогою подібного показника можна оцінити також якість кредитної діяльності банківської системи загалом, вибравши при цьому період, коли збалансованість кредитного портфеля була очевидною, а економічне зростання характеризувалося стійкими показниками.

Отже, в межах даної методики проведення експрес-діагностики якості кредитного портфеля банків виділяється наступний ряд найбільш узагальнених етапів:

1. Збір необхідної банківської інформації та оцінка її достовірності.

2. Оцінка дохідності кредитного портфеля за коефіцієнтом дохідності та рентабельністю портфеля.

3. Оцінка кредитного ризику портфеля за співвідношенням резервів до кредитного портфеля.

4. Оцінка ліквідності кредитного портфеля за нормативами Н7 та Н9.

5. Розрахунок інтегрального показника якості кредитного портфеля та інтерпретація результатів.

5. Визначення "узьких" місць та пошук резервів.

Аля проведення експрес-діагностики якості кредитного портфеля банків використано фінансову звітність п'яти великих установ (з кредитними портфелями більше 10 млрд. грн) та статистичні дані НБУ. Зокрема ПАТ "Укргазбанк" (банк 1), ПАТ "Райффайзен банк Аваль" (банк 2), ПАТ "Альфа банк" (банк 3), ПАТ "Перший Український міжнародний банк" (банк 4), ПАТ "Південний" (банк 5). Таким чином, обрано один банк з державною часткою, два банки іноземних банківських груп та два банки з приватним капіталом.

Оцінка дохідності портфеля передбачає розрахунок коефіцієнта дохідності та його 
Таблиця 2. Оцінка дохідності кредитного портфеля у 2015-2019 рр. (станом на 1 січня)

\begin{tabular}{|c|c|c|c|c|c|c|c|c|c|c|}
\hline Банки & 2015 & 2016 & 2017 & 2018 & 2019 & 2015 & 2016 & 2017 & 2018 & 2019 \\
\hline \multicolumn{6}{|c|}{ Дохідність портфеля \% } & \multirow{2}{*}{\multicolumn{5}{|c|}{ Бали по дохідності портфеля }} \\
\hline Банківська система & 19,68 & 19,70 & 25,05 & 22,61 & 23,71 & & & & & \\
\hline Банк 1 & 27,96 & 25,02 & 26,91 & 20,43 & 18,44 & 14 & 13 & 11 & 9 & 8 \\
\hline Банк 2 & 21,85 & 24,59 & 23,40 & 18,63 & 18,63 & 11 & 12 & 9 & 8 & 8 \\
\hline Банк 3 & 18,47 & 19,74 & 20,91 & 19,44 & 21,19 & 9 & 10 & 8 & 9 & 9 \\
\hline Банк 4 & 18,66 & 19,96 & 20,27 & 20,23 & 24,08 & 9 & 10 & 8 & 9 & 10 \\
\hline Банк 5 & 12,82 & 13,72 & 13,86 & 12,77 & 15,11 & 7 & 7 & 6 & 6 & 6 \\
\hline Разом & 19,85 & 20,97 & 21,62 & 18,85 & 19,63 & 10 & 11 & 9 & 8 & 8 \\
\hline \multicolumn{6}{|c|}{ Прибутковість кредитного портфеля } & \multirow{2}{*}{\multicolumn{5}{|c|}{ Бали по прибутковості кредитного портфеля }} \\
\hline Банківська система & 7,91 & 6,14 & 8,66 & 9,77 & 12,31 & & & & & \\
\hline Банк 1 & 10,74 & 5,18 & 3,56 & 7,01 & 7,04 & 14 & 8 & 4 & 7 & 6 \\
\hline Банк 2 & 16,24 & 15,70 & 17,59 & 15,29 & 14,81 & 20 & 20 & 20 & 16 & 12 \\
\hline Банк 3 & 6,71 & 4,38 & 6,83 & 9,87 & 11,66 & 8 & 7 & 8 & 10 & 9 \\
\hline Банк 4 & 9,05 & 8,17 & 8,50 & 11,81 & 15,11 & 11 & 13 & 10 & 12 & 12 \\
\hline Банк 5 & 4,15 & 3,53 & 3,32 & 5,13 & 7,30 & 5 & 6 & 4 & 5 & 6 \\
\hline Разом & 10,21 & 8,06 & 8,86 & 10,46 & 11,46 & 13 & 13 & 10 & 11 & 9 \\
\hline
\end{tabular}

прибутковості (табл. 2). Найбільшу дохідність на 1 січня 2019 р. мають кредитні портфелі ПАТ "Перший Український міжнародний банк" $(24,08 \%)$ та ПАТ "Альфа банк" (21,19\%), найменшу - ПАТ "Південний" (15,11\%). Необхідно вказати, що по сукупному портфелю вона коливалася в межах 18,85-21,62\%. На кінець періоду, що аналізується вона становила 19,63\%. Слід вказати, що у 2018 р. вона зросла у порівняні з попереднім роком. Це може бути пов'язано із підвищенням процентних ставок по кредитам. Аохідність портфеля банківської системи є досить високою. У 2015-2018 рр. коливалася в межах 19,68-25,05\%. Була вищою в останні роки ніж дохідність сукупного портфеля п'яти банків. Це можна пояснити суттєвим впливом націоналізації ПАТ "Приватбанк" на банківську систему та ії̈ основні показники. Бали по дохідності портфеля відображають цей вплив у 2017-2018 рр. Так, вони є нижчими, ніж у 2016 p. Тільки ПАТ "Перший Український міжнародний банк" в останньому році досяг по балам еталонного рівня банківської системи (10 балів).

Прибутковість скупного кредитного портфелю п'яти банків у 2015 р. впала з 10,21\% до $8,06 \%$. У наступних роках вона тільки зростала і на 1.01.2019 р. становила вже $11,46 \%$. Така тенденція спостерігається і по банківській системі в цілому. Падіння до 6,14\%, подальше зростання до 12,31\%. Серед обраних банків тільки у ПАТ "Райффайзен банк Аваль" та ПАТ "Перший Український міжнародний банк" прибутковість кредитного портфеля була вищою ніж по банківській системі. Так, у ПАТ "Райффайзен банк Аваль" цей показник коливався в межах 14,81-16,24\%. Найгірша ситуація у ПАТ "Південний". Прибутковість його портфеля $\epsilon$ дуже низькою, коливається в межах 3,32$7,30 \%$. Це пов'язано з високою вартістю його ресурсної бази. Відповідно, ПАТ "Райффайзен банк Аваль" має досить високі бали. Так, у 2015-2016 рр. вони сягали 20. У наступних роках вони зменшувалися і становили на 1.01 .2019 р. вже 12. ПАТ "Перший Український міжнародний банк" також мав бали вище еталонного рівня банківської системи (10 балів). Вони коливалися межах у 10-13 балів. У ПАТ "Південний" бали були найнижчими (4-6).

Аинаміку ризику кредитного портфеля, який розраховується як відношення резерву за кредитними операціями банку до суми кредитного портфеля, представлено в таблиці 3. Сукупний ризик кредитного портфеля банків коливався, у 2015 р. він зріс з 29,38\% до 59,99\%, у наступних роках почав скорочуватися і на 1.01.2019 р. становив 19,58\%. Протягом всього періоду, що аналізується ризик портфеля позичок ПАТ "Укргазбанк" коливався в межах $18,47 \%-74,52 \%$, ПАТ "Райффайзен банк Аваль" - 8,95\%-93,94\%, ПАТ "Альфа банк" $15,23 \%-93,94 \%$, ПАТ "Перший Український міжнародний банк" - 15,15\%-40,17\%, ПАТ "Південний" - 7,09\%-11,82\%. Можна спостерігати тенденцію зменшення ризику кредитного портфеля майже у всіх банків у 20162018 рр. Політика формування резервів носить досить різноплановий характер. Зменшення цього відношення в складних умовах не може бути підтвердженням поліпшення якості кредитного портфеля, а швидше викликано зростанням проблем. Однак можна стверджувати, що ситуація у 2016-2018 рр. поліпшилася в банківському секторі. Банки, що аналізуються, почали менше формувати резерви. Основні обсяги резервів були сформовані у 2014-2015 рр. Надалі вони почали їх списувати. Ризик кредитного портфеля по системі є досить високим. Це пояснюється націоналізацією ПАТ "Приватбанк". Банк почав формувати свої резерви у повному обсязі. Так, на 1.01.2019р. його резер- 
Таблиця 3. Оцінка кредитного ризику портфеля у 2015-2019 рр. (станом на 1 січня)

\begin{tabular}{|l|c|c|c|c|c|c|c|c|c|c|c|}
\hline \multicolumn{1}{|c|}{ Банки } & 2015 & 2016 & 2017 & 2018 & 2019 & 2015 & 2016 & 2017 & 2018 & 2019 \\
\hline \multicolumn{3}{|c|}{ Ризик кредитного портфеля, \% } & \multicolumn{3}{|c|}{ Бали по ризику кредитного портфеля } \\
\hline Банківська система & 19,68 & 19,70 & 25,05 & 22,61 & 23,71 & & & & & & \\
\hline Банк 1 & 27,96 & 25,02 & 26,91 & 20,43 & 18,44 & 0 & 7 & 16 & 17 & 18 \\
\hline Банк 2 & 21,85 & 24,59 & 23,40 & 18,63 & 18,63 & 0 & 0 & 9 & 18 & 19 \\
\hline Банк 3 & 18,47 & 19,74 & 20,91 & 19,44 & 21,19 & 12 & 9 & 16 & 17 & 17 \\
\hline Банк 4 & 18,66 & 19,96 & 20,27 & 20,23 & 24,08 & 12 & 11 & 15 & 17 & 16 \\
\hline Банк 5 & 12,82 & 13,72 & 13,86 & 12,77 & 15,11 & 16 & 18 & 19 & 19 & 19 \\
\hline Разом & 19,85 & 20,97 & 21,62 & 18,85 & 19,63 & 5 & 6 & 14 & 17 & 18 \\
\hline
\end{tabular}

Таблиця 4. Оцінка ліквідності кредитного портфеля у 2015-2019 рр. (станом на 1 січня)

\begin{tabular}{|c|c|c|c|c|c|c|c|c|c|c|}
\hline Банки & 2015 & 2016 & 2017 & 2018 & 2019 & 2015 & 2016 & 2017 & 2018 & 2019 \\
\hline \multicolumn{6}{|c|}{ Норматив Н7 (25\%) } & \multirow{2}{*}{\multicolumn{5}{|c|}{ Бали по нормативу Н7 }} \\
\hline Банківська система & 25 & 25 & 25 & 25 & 25 & & & & & \\
\hline Банк 1 & 33,54 & 43,14 & 32,19 & 19,55 & 19,66 & 7 & 3 & 7 & 20 & 12 \\
\hline Банк 2 & 18,56 & 26,85 & 19,64 & 11,2 & 10,13 & 13 & 9 & 12 & 16 & 16 \\
\hline Банк 3 & 23,7 & 74,73 & 51,49 & 42,87 & 33,46 & 11 & 0 & 0 & 3 & 7 \\
\hline Банк 4 & 21,29 & 36,64 & 104,86 & 173,81 & 15,3 & 11 & 5 & 0 & 0 & 14 \\
\hline Банк 5 & 24,53 & 31,82 & 34,94 & 33,46 & 22,67 & 10 & 7 & 6 & 7 & 11 \\
\hline & Нормати & $\mathrm{H} 9(5 \%$ & & & & & & & & \\
\hline Банківська система & 5 & 5 & 5 & 5 & 5 & & Бал & Іо норма & y9 & \\
\hline Банк 1 & 0,11 & 0,3 & 0,86 & 0,30 & 0,32 & 20 & 19 & 18 & 20 & 19 \\
\hline Банк 2 & 4,1 & 7,99 & 4,89 & 2,27 & 0,37 & 12 & 4 & 10 & 15 & 19 \\
\hline Банк 3 & 0,06 & 3,97 & 6,04 & 9,71 & 0,45 & 20 & 12 & 8 & 1 & 19 \\
\hline Банк 4 & 16,7 & 19,68 & 93,84 & \begin{tabular}{|l|}
173,81 \\
\end{tabular} & 83,16 & 0 & 0 & 0 & 0 & 0 \\
\hline Банк 5 & 4,39 & 20,89 & 34,62 & 40,65 & 10,02 & 11 & 0 & 0 & 0 & 0 \\
\hline
\end{tabular}

Таблиця 5. Інтегральна оцінка якості кредитного портфеля банків (станом на 1 січня)

\begin{tabular}{|l|l|l|l|l|l|l|}
\hline Банки & 2015 & 2016 & 2017 & 2018 & 2019 & Середні \\
\hline Банк 1 & 12 & 10 & 10 & 13 & 11 & 11 \\
\hline Банк 2 & 13 & 11 & 13 & 14 & 14 & 13 \\
\hline Банк 3 & 11 & 8 & 8 & 8 & 12 & 9 \\
\hline Банк 4 & 9 & 8 & 7 & 8 & 9 & 8 \\
\hline Банк 5 & 9 & 7 & 6 & 7 & 7 & 7 \\
\hline
\end{tabular}

ви становили 241 млрд грн, по системі загалом 545 млрд грн, тобто майже 44\%. У випадку, якщо його не враховувати, то ризик кредитного портфеля по системі буде становити лише 56,05\%

Відповідно, на початок 2017 р. та 2018 р. банки отримали досить високі бали в межах 1619. Слід вказати, що ПАТ "Укргазбанк" (на 1.01.2015 р.) та ПАТ "Райффайзен банк Аваль" (на 1.01.2015 та 1.01.2016 р.) мали резерви, що перевищували системний рівень у 2 рази. Отже, отримали 0 балів.

Иіквідність портфелів визначаємо по нормативам Н7 та Н9. Як свідчать дані таблиці 4, значення нормативу Н7 періодично не виконувалися обраними банками. Так, не виконував ПАТ "Укргазбанк" на 01.01.2015-2017 рр., ПАТ "Райффайзен банк Аваль" на 01.01.2016 р., ПАТ "Альфа банк" на 01.01.2016-2019 рр., ПАТ "Перший Український міжнародний банк" на 01.01.2016-2018 рр., ПАТ "Південний" на 01.01.2016-2018 рр. Відповідно, досить часто бали є досить низькими. ПАТ "Альфа банк" та ПАТ "Перший Український міжнародний банк" отримували 0 балів через перевищення їх значень нормативу у 2 рази і більше.
Аналогічна ситуація і з нормативом Н9. Не виконував ПАТ "Райффайзен банк Аваль" на 01.01.2016 рр., ПАТ "Альфа банк" на 01.01.2017— 2018 рр., ПАТ "Перший Український міжнародний банк" на всі дати, ПАТ "Південний" на 01.01.2016-2018. Останні дві банківські установи отримували 0 балів. ПАТ "Перший Український міжнародний банк" потягом всього періоду перевищував норматив у 2 рази і більше.

Загальні результати експрес-діагностики за інтегральною оцінкою якості свідчать, що ПАТ "Укргазбанк" та ПАТ "Райффайзен банк Аваль" у 2015-2018 рр. мали досить високу якість кредитного портфеля (середні значення інтегрального показника 11 та 13 балів) (табл. 5). Ситуація у ПАТ "Перший Український міжнародний банк" є гіршою (середнє значення 8). Аинаміка якості переважно пояснюється ліквідністю кредитного портфеля. Він не виконував норматив максимального розміру кредитів, гарантій та поручительств, наданих одному інсайдеру (Н9). У ПАТ "Альфа банк" періодично з'являлися проблеми з ліквідністю та прибутковістю портфеля, що пояснює середнє значення інтегрального показника 9 балів.

Складна ситуація з якість кредитного портфеля спостерігається у ПАТ "Південний". За останні чотири роки він мав значення інтегрального показника в межах 6-7 балів. По нормативу максимального розміру кредитів, гарантій 
Таблиця 6. Вхідні дані розрахунку факторів регресії

\begin{tabular}{|c|c|c|c|c|c|c|c|c|c|c|}
\hline Рік & $\mathrm{y}$ & $\mathrm{X}_{1}$ & $\mathrm{X}_{2}$ & $\mathrm{X}_{3}$ & $\mathrm{X}_{4}$ & $\mathrm{y}$ & $\mathrm{X}_{1}$ & $\mathrm{x}_{2}$ & $\mathrm{x}_{3}$ & $\mathrm{X}_{4}$ \\
\hline \multicolumn{6}{|c|}{ Банк 1} & \multicolumn{5}{|c|}{ Банк 2} \\
\hline 2015 & 12 & 47,72 & 85,47 & 71,70 & 1,62 & 13 & 63,39 & 70,52 & 58,00 & 3,90 \\
\hline 2016 & 10 & 33,76 & 89,45 & 57,79 & 1,26 & 11 & 49,32 & 73,55 & 74,70 & 2,77 \\
\hline 2017 & 10 & 37,75 & 94,13 & 71,87 & 1,15 & 13 & 50,01 & 81,63 & 85,18 & 4,03 \\
\hline 2018 & 13 & 48,52 & 94,88 & 52,75 & 1,52 & 14 & 47,69 & 89,48 & 80,47 & 5,58 \\
\hline 2019 & 11 & 48,94 & 93,87 & 56,90 & 1,62 & 14 & 56,90 & 89,98 & 74,65 & 4,88 \\
\hline \multicolumn{6}{|c|}{ Банк 3} & \multicolumn{5}{|c|}{ Банк 4} \\
\hline 2015 & 11 & 69,79 & 81,06 & 42,95 & 1,57 & 9 & 72,90 & 88,03 & 45,32 & 1,94 \\
\hline 2016 & 8 & 64,83 & 85,65 & 36,07 & 1,29 & 8 & 69,83 & 87,77 & 42,50 & 1,69 \\
\hline 2017 & 8 & 65,79 & 79,55 & 31,31 & 1,48 & 7 & 55,57 & 86,14 & 48,04 & 1,72 \\
\hline 2018 & 8 & 48,70 & 69,51 & 41,14 & 2,03 & 8 & 46,67 & 77,75 & 56,82 & 2,40 \\
\hline 2019 & 12 & 46,68 & 61,94 & 48,34 & 2,22 & 9 & 46,02 & 69,46 & 70,57 & 2,68 \\
\hline \multicolumn{6}{|c|}{ Банк 5} & & & & & \\
\hline 2015 & 9 & 71,76 & 96,54 & 41,71 & 1,48 & & & & & \\
\hline 2016 & 7 & 61,61 & 97,57 & 36,45 & 1,35 & & & & & \\
\hline 2017 & 6 & 65,74 & 98,09 & 36,34 & 1,31 & & & & & \\
\hline 2018 & 7 & 58,55 & 98,37 & 36,10 & 1,67 & & & & & \\
\hline 2019 & 7 & 58,44 & 98,56 & 47,20 & 1,93 & & & & & \\
\hline
\end{tabular}

та поручительств, наданих одному інсайдеру (H9) банківська установа не набрала балів зовсім. Крім того, ПАТ "Південний" мав досить низьку прибутковість портфеля.

У зв'язку із зростанням обсягів проведення кредитних операцій постає необхідність удосконалення наявних методів підвищення якості власного кредитного портфеля. Виникає потреба у виявленні екзогенних чинників, які обумовлюють якість такого портфеля, що формує підгрунтя для застосування сучасних інструментів економетричного моделювання фінансово-економічних процесів.

Інтегральний показник якості кредитного портфеля приймаємо за залежну величину (у). На цей показник можуть впливати різні фактори, а саме: питома вага кредитних портфелів в загальній сумі банківських активів - $\mathrm{x}_{1}$ (відображає тип кредитної політики банків); частка кредитів суб'єктам господарювання в портфелі - x $_{2}$ (характеризує пріоритетність кредитування корпоративного сектору); питома вага кредитів в національній валюті в портфелі - $\mathrm{x}_{3}$ (відображає структуру портфелів за видами валют); співвідношення процентних доходів та процентних витрат - x $_{4}$; (характеризує рентабельність кредитних операцій).

У таблиці 6 наведено вхідні дані розрахунку факторів регресії, яка пояснить ступінь впливу чотирьох факторів на інтегральний показник якості кредитного портфеля.

Результати регресійного аналізу остаточної моделі наведено в таблиці 7. За t-статистикою змінні $\mathrm{x}_{3}$ та $\mathrm{x}_{4}$ значимі. Інші змінні відкинуто оскільки їх t-статистика не відповідає нормативу $\left(\mathrm{x}_{1}\right.$ та $\left.\mathrm{x}_{2}\right)$. Регресійна статистика для двохфакторної економетричної моделі: коефіцієнти коре- ляції та детермінації - 0,759 та 0,576; фактичне значення F-критерію Фішера - 14,944. Отже, двохфакторна модель є адекватною.

Отже, для банків, що аналізуються, факторами впливу на якість їх кредитних портфелів є: по-перше, структура портфелів за видами валют (коефіцієнт 0,078); по-друге, рентабельність кредитних операцій (коефіцієнт 0,675). Завдяки відповідній та зваженій політиці установи можуть підвищити якість власних портфелів шляхом забезпечення зростання питомої ваги позичок в національній валюті, а також збільшення співвідношення процентних доходів та витрат.

\section{ВИСНОВКИ З ПРОВЕДЕНОГО ДОСЛІДЖЕННЯ I ПЕРСПЕКТИВИ ПОДАЛЬШИХ РОЗВІДОК У ЦЬОМУ НАПРЯМI}

У процесі дослідження встановлено, що кредитний портфель - це структурована за певними критеріями якості сукупність кредитів, виданих банківською установою відповідно до її кредитної політики. Його якість визначається властивістю забезпечити максимально можливу процентну прибутковість кредитних операцій при допустимих рівнях ліквідності та кредитного ризику. У загальному вигляді ризик, прибутковість та ліквідність є суттєвими властивостями якості будь-якого портфеля активів, який формується банком.

Таблиця 7. Результати регресійного аналізу двохфакторної моделі

\begin{tabular}{|l|l|l|l|l|l|}
\hline Показники & Коефіцієнти & Стандартна помилка & $\begin{array}{c}\text { t- } \\
\text { статистика }\end{array}$ & $\begin{array}{c}\text { Нижні } \\
95 \%\end{array}$ & $\begin{array}{c}\text { Верхні } \\
95 \%\end{array}$ \\
\hline $\mathrm{Y}$ & 4,130 & 1,216 & 3,396 & 1,608 & 6,651 \\
\hline $\mathrm{x}_{3}$ & 0,078 & 0,029 & 2,694 & 0,018 & 0,138 \\
\hline $\mathrm{x}_{4}$ & 0,675 & 0,388 & 1,939 & 0,130 & 1,480 \\
\hline
\end{tabular}


Визначено, що експрес-діагностика якості кредитного портфеля банків повинна будуватися на інтегральній оцінці, яка враховує сукупність чинників із застосуванням прийнятих сьогодні критеріїв якості кредитного портфеля. Результати експрес-діагностики якості кредитного портфеля банківських установ свідчать, що після останньої фінансової кризи стан їх портфелів став поліпшуватися. Хоча для деяких банків якість кредитного портфеля залишається низькою переважно через проблеми 3 ліквідністю портфеля. $€$ банки, які не в змозі виконати норматив Н9. Банківським установам необхідно проводити комплексну політику забезпечення якості кредитного портфеля, для того щоб підвищити конкурентоспроможність та гарантувати безпеку функціонування в умовах невизначеності і перманентних фінансовоекономічних криз.

Встановлено, що екзогенними факторами впливу на якість кредитних портфелів виступають: 1) структура портфелів за видами валют; 2) рентабельність кредитних операцій. Отже, шляхом забезпечення зростання питомої ваги позичок у національній валюті, а також збільшення співвідношення процентних доходів та витрат банківські установи можуть підвищити якість власних портфелів.

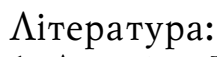

1. Авсейко М.Н. Методика оценки и сравнения качества кредитных портфелей банков. Банкаўскі веснік. 2008. Аістапад. С. 36-40.

2. Басс А.Б. Современные проблемы качества кредитного портфеля. Международный научный журнал "Инновационная наука". 2016. № 4. C. 42-46.

3. Волкова Н.І., Кункель А.О. Тенденції та особливості кредитної діяльності вітчизняних банків на сучасному етапі розвитку економіки. Економіка і організація управління. 2018. № 1 (29). C. 52-63.

4. Ааврушин О.И., Мамонтова И.А., Валенцова Н.И. Банковское дело. Москва, Кнорус, 2009.768 c.

5. Аарионова И.В. Риск-менеджмент в коммерческом банке: монография. Москва, Кноpyc, 2014. $456 \mathrm{c}$.

6. Методика розрахунку економічних нормативів регулювання діяльності банків в Україні. Національний банк України. URL: https:/ /bank.gov.ua/document/download?docId=28624809 (дата звернення: 20.10.2019).

7. Роуз П. С. Банковский менеджмент: Предоставление финансовых услуг. Москва, Аело $\Lambda \mathrm{TA}, 1995.743 \mathrm{c}$.
8. Тавасиев А.М. Банковское дело. Управление и технологии. Москва, Юнити-Аана, 2005.671 c.

9. Терновская Е.П., Гребеник Т.В. Качество кредитного портфеля российских банков: особенности оценки и управления. Интернет-журнал "Науковедение", 2014. № 3. URL: http://publ.naukovedenie.ru (дата обращения: 20.10.2019).

10. Эйхлер А.В., Гавриленко Н.Г. Аиагностика экономического состояния предприятий по техническому обслуживанию и ремонту автомобилей в системе антикризисного управления: монография. Омск, СибААИ, 2007. 108 с.

\section{References:}

1. Avsejko, M.N. (2008), "Methodology for assessing and comparing the quality of bank loan portfolios", Bankovski vesnik, Listapad, pp. 36-40.

2. Bass, A.B. (2016), "Modern problems of loan portfolio quality", Mezhdunarodnyj nauchnyj zhurnal "Innovacionnaja nauka", vol. 4, pp. 42-46.

3. Volkova, N.I. Kunkel', A.O. (2018), "Trends and features of lending activities of domestic banks at the current stage of economic development", Ekonomika i orhanizatsiia upravlinnia, vol. 1 (29), pp. 52-63.

4. Lavrushin, O.I. Mamontova, I.D. Valencova, N.I. (2009), Bankovskoe delo [Banking], Knorus, Moskva, Russia.

5. Larionova, I.V. (2014), Risk-menedzhment v kommercheskom banke: monografija [Risk management in a commercial bank: monograph], Knorus, Moskva, Russia.

6. The official site of National Bank of Ukraine (2019), "Methods of economic norms calculation for regulation of banks in Ukraine", available at: URL: https://bank.gov.ua/document/download?docId $=28624809$ (Accessed 20 October 2019).

7. Rouz, P.S. (1995), Bankovskij menedzhment: Predostavlenie finansovyhuslug [Banking Management: Financial Services], Delo LTD, Moskva, Russia.

8. Tavasiev, A.M. (2005), Bankovskoe delo. Upravlenie i tehnologii [Banking. Management and Technology], Juniti-Dana, Moskva, Russia.

9. Ternovskaja, E.P.Grebenik, T.V.(2014), "The quality of the loan portfolio of Russian banks: features of assessment and management", Internet-zhurnal "Naukovedenie", vol. 3, available at: URL: http:// publ.naukovedenie.ru (Accessed 21 October 2019).

10. Jejhler, L.V. Gavrilenko, N.G. (2007), Diagnostika jekonomicheskogo sostojanija predprijatij po tehnicheskomu obsluzhivaniju i remontu avtomobilej v sisteme antikrizisnogo upravlenija: monografija. [Diagnosis of the economic condition of enterprises for maintenance and repair of cars in the crisis management system: monograph], SibADI, Omsk, Russia.

Стаття надійшла до редакиї 26.10.2019 p. 